\title{
Microwave-Assisted Preparation of Poly(fluorene)s by Ni-Catalyzed Polymerization
}

\author{
By Shinpei MiYAmoto,${ }^{1}$ Susumu TaNaKA,${ }^{1}$ Jun-ichi SugIYAMA, ${ }^{1, *}$ \\ Kenji MACHIDA, ${ }^{2}$ Shunzo SUEMATSU, ${ }^{2}$ and Kenji TAMAMITSU ${ }^{2}$
}

A series of poly(fluorene)s was prepared from 9,9-dialkylated-2,7-dibromofluorenes by Ni-catalyzed polymerization (Yamamoto coupling reaction) under microwave irradiation. Compared to the oil heating bath method (24 h, $M_{\mathrm{w}} 12800$, yield $82 \%$ ), microwave irradiation of 9,9-di- $n$-octyl-2,7-dibromofluorene produced poly[2,7-(9,9-di- $n$-octylfluorene)] with a high molecular weight $\left(M_{\mathrm{w}} 24200\right)$ and yield $(88 \%)$ in a short time $(180 \mathrm{~min})$. Hence, the microwave irradiation method effectively shortened the reaction time and increased the molecular weight of the prepared poly(fluorene)s.

KEY WORDS: Microwave-Assisted Preparation / Ni-Catalyzed Polymerization / 2,7-Dibromofluorenes /

Conjugated polymers have received much attention due to their unusual optical and electrical properties. In addition to being used to fabricate light-emitting devices, these polymers have recently been employed in electronic and photonic devices, polarizers for liquid crystal displays, active media in solid-state plastic lasers, and polymer-based photovoltaic cells. ${ }^{1-7}$ In conjugated polymers, poly(fluorene)s exhibit a high performance for the photoelectronic property; thus, numerous chemists are interested poly(fluorene)s and their specific properties.

These polymers are prepared by transition metal-catalyzed organic transformations, which have been demonstrated as powerful methods for constructing macromolecules with welldefined architectures. ${ }^{8,9}$ In particular, employing a metal catalyst for $\mathrm{C}-\mathrm{C}$ bond formation of aromatic hydrocarbons ${ }^{10}$ has produced several conjugated polymers. Yamamoto et al. have reported the synthesis of polymers using Ni-catalyzed coupling polymerization of aryl dihalides; that is, $\operatorname{poly}(p$ phenylene) was synthesized from the Grignard reagent of $p$ dibromobenzene ${ }^{11}$ and poly(2,5-thienylene) from 2,5-dihalothiophenes in the presence of zinc. ${ }^{12}$ Furthermore, Ueda et al. successfully synthesized aromatic polymers by Ni-catalyzed coupling of aromatic dihalides. ${ }^{13}$ However, preparing such $\pi$ conjugated polymeric materials often involves metal-catalyzed cross-coupling reactions, and frequently requires a reaction time in excess of $24 \mathrm{~h}$ to yield high molecular weight materials.

Our group, which focuses on microwave chemistry, has shown that microwave heating efficiently reduces reaction times and increases reaction yields, while simultaneously reducing the amount of side products. ${ }^{14-17}$ To date, few examples of $\pi$-conjugated polymers prepared by microwave irradiation have been reported, but microwave chemistry should be beneficial in the area of $\pi$-conjugated polymer chemistry. Herein, we report the synthesis of 9,9-dialkylated poly(fluorene)s using microwave irradiation and a Ni-catalyzed polymerization method.

\section{EXPERIMENTAL}

\section{Materials and Measurements}

Reagents and solvents were purchased from Aldrich Co., Tokyo Chemical Industry Co., and Wako Pure Chemical Industries. Microwave heating was carried out by CEM Discover $(2.45 \mathrm{GHz}$, max power $300 \mathrm{~W})$. The ${ }^{1} \mathrm{H}$ Nuclear Magnetic Resonance (NMR) spectra of the polymers were recorded on a JEOL JNM-LA600 spectrometer operated at $600 \mathrm{MHz}$ in pulse Fourier transform mode. Tetramethylsilane (TMS) was used as an internal reference. Gel permeation chromatography (GPC) was performed on a TOSOH GPC assembly, which consisted of a model DP-8020 pump, a model RI-8020 refractive index detector, UV-8020 refractive index detector, and two GPC gel columns (TSKgel Super HM-H). Polystyrene standards were used for calibration, and THF was used as the mobile phase with a flow rate of $0.6 \mathrm{~mL} /$ $\min$.

\section{General Procedure for Polymerization}

Dry solvent $(2.0 \mathrm{~mL})$ was added to a flask charged with 2,7dibromo-9,9-di- $n$-octylfluorene 1c $(548 \mathrm{mg}, 1.0 \mathrm{mmol}), \mathrm{NiCl}_{2}$ $(9.1 \mathrm{mg}, 0.07 \mathrm{mmol})$, triphenylphosphine $(73.4 \mathrm{mg}, 0.28 \mathrm{mmol})$, 2,2'-bipyridine $(6.6 \mathrm{mg}, 0.04 \mathrm{mmol})$, and zinc powder $(203 \mathrm{mg}$, $3.1 \mathrm{mmol})$. The flask was then evacuated and filled with nitrogen. The mixture was stirred and irradiated with microwaves (or heated in an oil bath). After the reaction, the catalyst and unreacted zinc powder were dissolved in hydrochloric acid $(12 \mathrm{~N}, 3 \mathrm{~mL})$. The reacted mixture was poured into methanol $(20 \mathrm{~mL})$. The precipitated material was collected by filtration, and subsequently washed with distilled water, methanol, and acetone. The solid was dissolved in THF and reprecipitated with methanol. The yellow precipitate was filtered and dried in vacuo. The obtained polymer was dissolved in THF and $\mathrm{CHCl}_{3}$.

\footnotetext{
${ }^{1}$ National Institute of Advanced Industrial Science and Technology (AIST), AIST Central 5, 1-1-1 Higashi, Tsukuba 305-8565, Japan

${ }^{2}$ Nippon Chemi-Con Corporation, 363, Arakawa, Takahagi 318-8505, Japan

*To whom correspondence should be addressed (Tel: +81-29-861-6383, Fax: +81-42-861-6242, E-mail: sugiyama-j@aist.go.jp).
} 


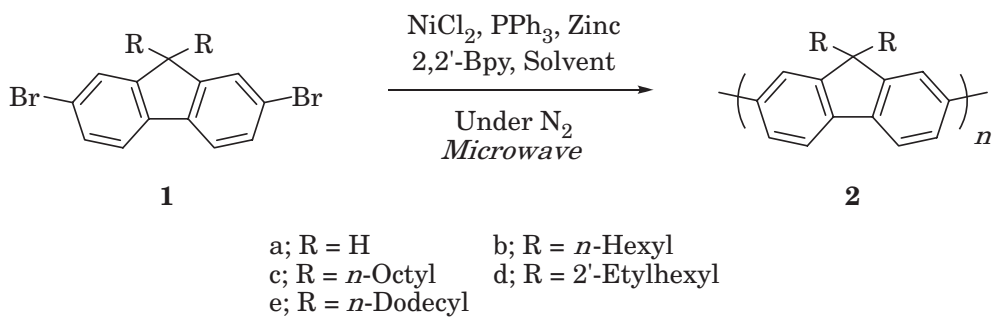

Figure 1. Microwave-assisted preparation conditions of poly(fluorene)s by Ni-catalyzed coupling polymerization.

Poly(2,7-fluorene) 2a. ${ }^{1} \mathrm{H}$ NMR $\left(\mathrm{CDCl}_{3}\right): \delta(\mathrm{ppm}) 7.84(2 \mathrm{H}, d)$, $7.69(2 \mathrm{H}, d), 7.55(2 \mathrm{H}, d d), 3.98(2 \mathrm{H}, \mathrm{s})$.

Poly[2,7-(9,9-di- $n$-hexylfluorene)] 2b. ${ }^{1} \mathrm{H} \mathrm{NMR}\left(\mathrm{CDCl}_{3}\right): \delta$ (ppm) $7.84(2 \mathrm{H}, d), 7.70(4 \mathrm{H}, m), 2.12(4 \mathrm{H}, m), 1.14(24 \mathrm{H}, m)$, $0.83(6 \mathrm{H}, t) .{ }^{13} \mathrm{C} \mathrm{NMR}\left(\mathrm{CDCl}_{3}\right): \delta(\mathrm{ppm}) 151.8,140.5,140.0$, $126.2,121.5,120.0,55.35,40.37,31.48,29.68,23.87,22.56$, 14.03 .

Poly[2,7-(9,9-di-n-octylfluorene)] 2c. ${ }^{1} \mathrm{H}$ NMR $\left(\mathrm{CDCl}_{3}\right): \quad \delta$ (ppm) $7.85(2 \mathrm{H}, d), 7.68(4 \mathrm{H}, m), 2.15(4 \mathrm{H}, m), 1.20(24 \mathrm{H}$, $m), 0.80(6 \mathrm{H}, t) .{ }^{13} \mathrm{C} \mathrm{NMR}\left(\mathrm{CDCl}_{3}\right): \delta(\mathrm{ppm}) 151.8,140.5$, 140.0, 126.2, 121.5, 120.0, 55.34, 40.39, 40.36, 31.79, 30.04, 29.22, 23.91, 22.59, 14.05 .

Poly $\{2,7-[9,9-$ di-(2'-ethylhexyl)fluorene $]\} \quad$ 2d. $\quad{ }^{1} \mathrm{H}$ NMR $\left(\mathrm{CDCl}_{3}\right): \delta(\mathrm{ppm}) 7.81(2 \mathrm{H}, d), 7.63(4 \mathrm{H}, m), 2.10(4 \mathrm{H}, m)$, $0.90(18 \mathrm{H}, m), 0.68(6 \mathrm{H}, t), 0.60(6 \mathrm{H}, t) .{ }^{13} \mathrm{C} \mathrm{NMR}\left(\mathrm{CDCl}_{3}\right): \delta$ (ppm) 151.8, 140.5, 140.0, 126.2, 121.5, 120.0, 55.34, 40.39, 40.36, 31.79, 30.04, 29.22, 23.91, 22.59, 14.05.

Poly[2,7-(9,9-di- $n$-dodecylfluorene)] 2e. ${ }^{1} \mathrm{H}$ NMR $\left(\mathrm{CDCl}_{3}\right): \delta$ (ppm) $7.83(2 \mathrm{H}, d), 7.68(4 \mathrm{H}, m), 2.12(4 \mathrm{H}, m), 1.17(40 \mathrm{H}, m)$, $0.86(6 \mathrm{H}, t) .{ }^{13} \mathrm{C} \mathrm{NMR}\left(\mathrm{CDCl}_{3}\right): \delta(\mathrm{ppm}) 151.8,140.5,140.3$, 126.2, 120.0, 55.34, 40.39, 31.94, 30.09, 29.98, 29.66, 29.63, $29.59,29.35,29.31,23.98,22.69,14.12$.

\section{RESULTS AND DISCUSSION}

$\mathrm{Ni}(0)$-mediated aryl-aryl bond formation has been used in the homo-coupling of aryl halides as well as to efficiently prepare di-, oligo-, and polyaryls. However, zero-valent nickel reagents are difficult to handle because they are air-sensitive and must be prepared via sophisticated techniques. Employing a $\mathrm{Ni}(\mathrm{II})$ salt in the presence of zinc as a reducing agent overcomes this issue. ${ }^{18}$ This procedure has been used to produce homo-coupling compounds of aryl halides in high yields when polar solvents such as DMF and DMAc are used. We prepared poly(fluorene)s by irradiating with microwaves from 9,9-dialkylated 2,7-dibromofluorene (1a-e), and the results are shown in Figure 1.

To determine the optimal conditions for microwave-assisted polymerization, polymerization of 2,7-dibromo-9,9-di- $n$-octylfluorene (1c) was studied in detail. Figure 2 shows the effect of the amount of $\mathrm{NiCl}_{2}$ on the polymerization. The molecular weight and yield of polymer (2c) indicated a high value with $7 \mathrm{~mol} \%$ of the catalyst based on the monomer. At the latter period of polymerization, the nickel chloride produces the surplus of monoaryl adduct with consuming the aryl halide, and

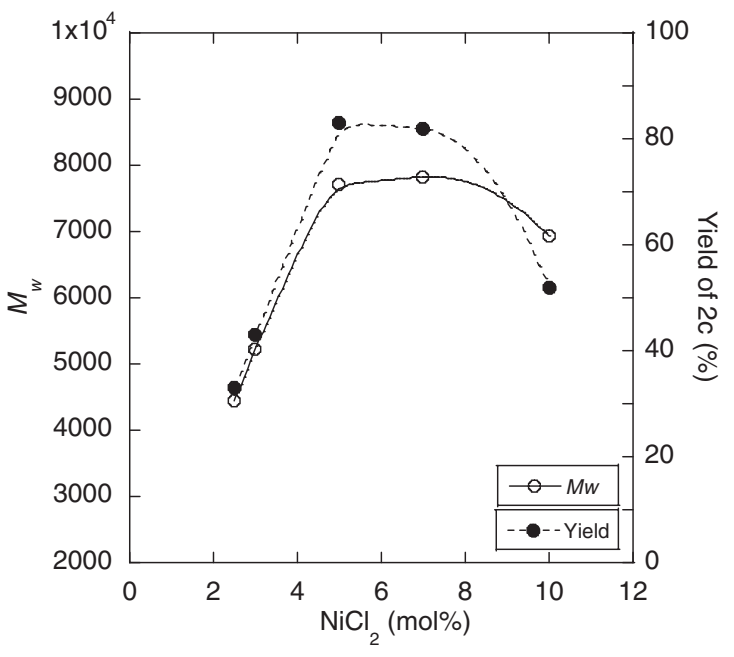

Figure 2. Effect of the amount of catalyst. Monomer 1c $(1.0 \mathrm{mmol}), \mathrm{PPh}_{3}$ $(0.10 \mathrm{mmol})$, zinc $(3.1 \mathrm{mmol}), 2,2^{\prime}$-bpy $(0.05 \mathrm{mmol})$, DMF $(2.0 \mathrm{~mL})$, temperature $\left(80^{\circ} \mathrm{C}\right.$, microwave power: $\left.\max 200 \mathrm{~W}\right)$, reaction time (180 min).

it will reduce the formation of diaryl adduct by the deficiency of the aryl halide. Therefore, it is guessed that molecular weight and yield lower, since the coupling reaction of oligomers are suppressed. In the range of $60^{\circ} \mathrm{C}$ to $120^{\circ} \mathrm{C}$, polymerization at $80^{\circ} \mathrm{C}$ showed the highest yield and molecular weight (Figure 3). In this polymerization reaction, it is reported that the active species is decomposed thermally. ${ }^{19}$ The molecular weight and yield will not increase in the reaction over $80^{\circ} \mathrm{C}$ for the decomposition to become predominant. Next, the effect of the ratio of zinc to nickel catalyst on polymerization was investigated (Figure 4). Because the ratedetermining step has been reported to be a reduction process involving nickel and zinc metal in the presence of excess aryl halide, an excess of zinc was required to form a high molecular weight polymer. ${ }^{18}$

In addition, the influence of the ratio of triphenylphosphine and 2,2'-bipyridine to the nickel catalyst on polymerization was examined (Figure 5). Two different catalyst ratios worked effectively: $\mathrm{PPh}_{3} / \mathrm{NiCl}_{2}$ in a ratio of $4: 1$ and $2,2^{\prime}$-bpy/ $\mathrm{NiCl}_{2}$ in a ratio of $1: 6$. The molecular weight and yield of the obtained polymer decreased upon the addition of a large excess of ligands to $\mathrm{NiCl}_{2}$ because $\mathrm{Ni}^{0}$-ligands are stably formed, which influence the oxidative addition of aromatic halides. 


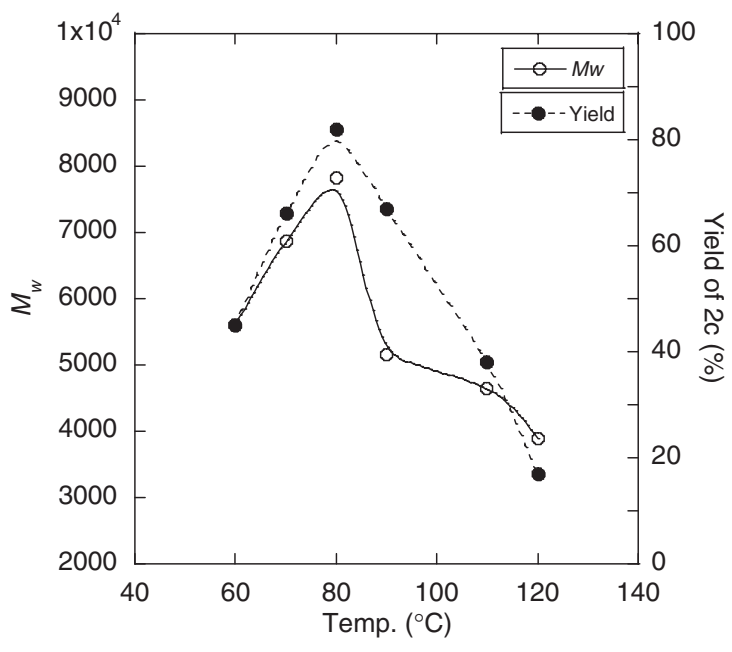

Figure 3. Effect of the reaction temperature. Monomer 1c $(1.0 \mathrm{mmol})$, $\mathrm{NiCl}_{2}(0.07 \mathrm{mmol}), \mathrm{PPh}_{3}(0.10 \mathrm{mmol})$, zinc $(3.1 \mathrm{mmol}), 2,2^{\prime}$-bpy $(0.05 \mathrm{mmol})$, DMF $(2.0 \mathrm{~mL})$, microwave power $(\max 200 \mathrm{~W})$, reaction time $(180 \mathrm{~min})$.

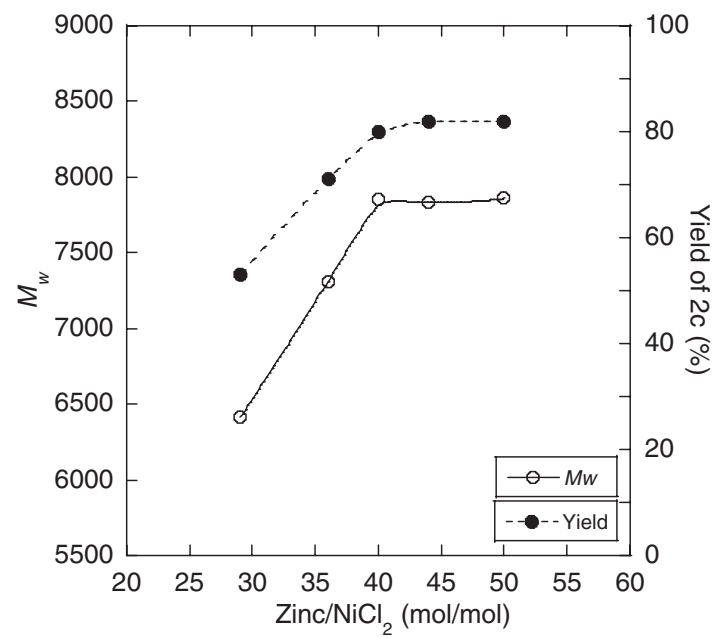

Figure 4. Effect of the amount of zinc. Monomer 1c $(1.0 \mathrm{mmol}), \mathrm{NiCl}_{2}$ $(0.07 \mathrm{mmol}), \mathrm{PPh}_{3}(0.10 \mathrm{mmol}), 2,2^{\prime}$-bpy $(0.05 \mathrm{mmol}), \mathrm{DMF}$ $(2.0 \mathrm{~mL})$, temperature $\left(80^{\circ} \mathrm{C}\right.$, microwave power: $\left.\max 200 \mathrm{~W}\right)$, reaction time $(180 \mathrm{~min})$

Table I shows the changes in the molecular weight and yield as the polymerization reaction time increases. In the case of a shorter reaction time (Entry 1), the molecular weight and yield showed low values. On the other hand, the extending the reaction time gave a higher molecular weight and yield polymer. However, if $180 \mathrm{~min}$ is the boundary, then the polymerization reaction shows a fixed numerical value on molecular weight (Entries 4-6). Generally, the reactivity of the oligomer decreases because the solubility in DMF decreases with increased molecular weight.

Thus, to increase the solubility, a DMF/toluene mixed solvent was used (Table II). Decreasing the content of the DMF volume to a ratio of 20/80 achieved a high molecular weight polymer (Entries 1-5). However, in 10/90 and 0/100 volume ratios, most of the reacted mixture was the monomer

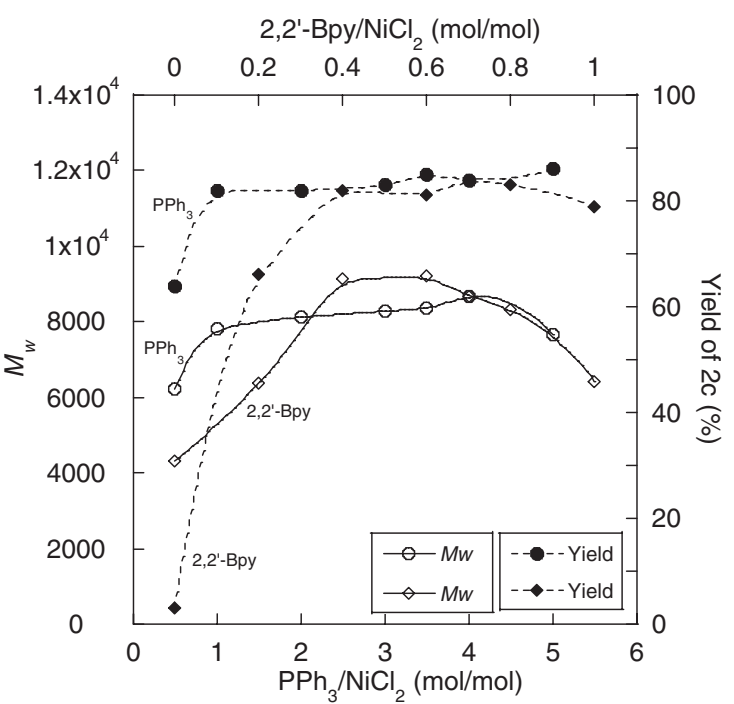

Figure 5. Effect of the amount of ligand to $\mathrm{NiCl}_{2}$. Scope of amount of $\mathrm{PPh}_{3}$ : monomer $1 \mathrm{c}(1 \mathrm{mmol}), \mathrm{NiCl}_{2}(0.07 \mathrm{mmol})$, zinc $(3.1 \mathrm{mmol}), 2,2^{\prime}$ bpy $(0.05 \mathrm{mmol})$, DMF $(2.0 \mathrm{~mL})$, temperature $\left(80^{\circ} \mathrm{C}\right.$, microwave power: $\max 200 \mathrm{~W})$, reaction time $180 \mathrm{~min}$. Scope of amount of 2,2'-bpy: monomer 1c (1 mmol), $\mathrm{NiCl}_{2}(0.07 \mathrm{mmol}), \mathrm{PPh}_{3}$ $(0.28 \mathrm{mmol})$, zinc $(3.1 \mathrm{mmol})$, DMF $(2.0 \mathrm{~mL})$, temperature $\left(80^{\circ} \mathrm{C}\right.$ microwave power: $\max 200 \mathrm{~W})$, reaction time.

Table I. Changes in Molecular Weight and Yield by Increasing the Reaction Time ${ }^{a}$

\begin{tabular}{ccccc}
\hline Entry & $\begin{array}{c}\text { Reaction time } \\
(\min )\end{array}$ & $M_{\mathrm{w}}{ }^{\mathrm{b}}$ & $M_{\mathrm{w}} / M_{\mathrm{n}}{ }^{\mathrm{b}}$ & $\begin{array}{c}\text { Yield } \\
(\%)\end{array}$ \\
\hline 1 & 20 & 5800 & 1.40 & 34 \\
2 & 40 & 7100 & 1.47 & 70 \\
3 & 80 & 7600 & 1.42 & 77 \\
4 & 180 & 9200 & 1.54 & 81 \\
5 & 240 & 9000 & 1.75 & 84 \\
6 & 300 & 8800 & 1.72 & 89 \\
\hline
\end{tabular}

${ }^{a}$ Reaction condition: 2,7-Dibromo-9,9-di- $n$-octylfluorene $(1.0 \mathrm{mmol})$ $\mathrm{NiCl}_{2}(0.07 \mathrm{mmol})$, zinc $(3.1 \mathrm{mmol}), \mathrm{PPh}_{3}(0.28 \mathrm{mmol}), 2,2^{\prime}$-bpy $(0.042$ $\mathrm{mmol})$, DMF $(2 \mathrm{~mL})$, temperature $\left(80^{\circ} \mathrm{C}\right.$, microwave power: max $\left.200 \mathrm{~W}\right)$. ${ }^{b}$ Determined by GPC analysis.

Table II. Effect of Molecular Weight and Yield by Improving the Solubility using the Solvent Volume Ratio Change ${ }^{a}$

\begin{tabular}{ccccc}
\hline Entry & $\begin{array}{c}\text { Solvent ratio } \\
(\text { DMF/Toluene) }\end{array}$ & $M_{\mathrm{w}}{ }^{\mathrm{b}}$ & $M_{\mathrm{w}} / M_{\mathrm{n}}{ }^{\mathrm{b}}$ & $\begin{array}{c}\text { Yield } \\
(\%)\end{array}$ \\
\hline 1 & $100 / 0$ & 9200 & 1.54 & 81 \\
2 & $80 / 20$ & 9200 & 1.83 & 88 \\
3 & $50 / 50$ & 19800 & 2.32 & 88 \\
4 & $20 / 80$ & 22500 & 2.25 & 89 \\
5 & $15 / 85$ & 13000 & 1.89 & 80 \\
6 & $10 / 90$ & & & $0^{\mathrm{c}}$ \\
7 & $0 / 100$ & & & $0^{\mathrm{d}}$ \\
\hline
\end{tabular}

a 2,7-Dibromo-9,9-di- $n$-octylfluorene $(1.0 \mathrm{mmol}), \mathrm{NiCl}_{2}(0.07 \mathrm{mmol})$, zinc (3.1 mmol), $\mathrm{PPh}_{3}(0.28 \mathrm{mmol}), 2,2^{\prime}$-bpy $(0.042 \mathrm{mmol})$, solvent $(2 \mathrm{~mL})$, temperature $\left(80^{\circ} \mathrm{C}\right.$, microwave power: $\left.\max 200 \mathrm{~W}\right), 180 \mathrm{~min}$. ${ }^{\mathrm{b}}$ Determined by GPC analysis. ${ }^{c}$ Recovery $92 \%$. ${ }^{d}$ Recovery $97 \%$.

(Entries 6 and 7). Colon and Kelsey have proposed that the catalytic cycle progresses through $\mathrm{Ni}^{3+}$ species (species II and III) in this catalytic reaction (Figure 6). Zinc in a polar solvent, such as DMF, easily reduces the active species I as electron transfer is frequent, and the polymerization reaction progresses. 


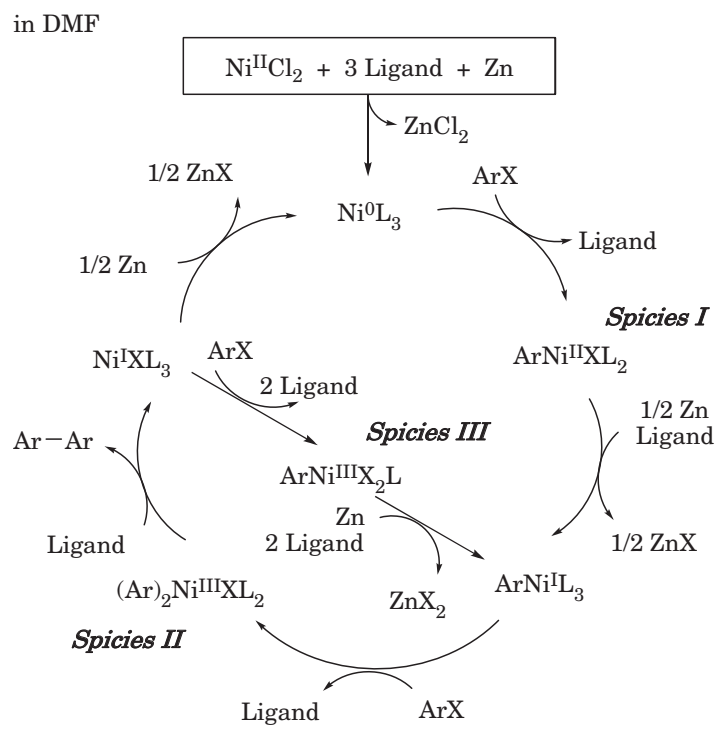

in toluene

Figure 6. Changes in the active state of nickel in DMF and toluene.

Table III. Effect of Microwave Irradiation Time in a DMF/toluene Mixed Solvent, and Comparison with the Oil Bath Heating Method ${ }^{\mathrm{a}}$

\begin{tabular}{ccrrrr}
\hline Entry & Method $^{\mathrm{b}}$ & $\begin{array}{r}\text { Reaction time } \\
(\mathrm{min})\end{array}$ & $M_{\mathrm{w}}{ }^{\mathrm{c}}$ & $M_{\mathrm{w}} / M_{\mathrm{n}}{ }^{\mathrm{c}}$ & $\begin{array}{c}\text { Yield } \\
(\%)\end{array}$ \\
\hline 1 & $\mathrm{MW}$ & 40 & & & $0^{\mathrm{d}}$ \\
2 & $\mathrm{MW}$ & 50 & 6700 & 1.32 & 14 \\
3 & $\mathrm{MW}$ & 80 & 8500 & 1.47 & 45 \\
4 & $\mathrm{MW}$ & 120 & 17400 & 1.95 & 84 \\
5 & $\mathrm{MW}$ & 180 & 22500 & 2.25 & 89 \\
6 & $\mathrm{MW}$ & 240 & 19600 & 2.01 & 89 \\
7 & $\mathrm{MW}$ & 300 & 19300 & 2.18 & 87 \\
8 & $\mathrm{OB}$ & 180 & 12300 & 1.77 & 60 \\
9 & $\mathrm{OB}$ & 1440 & 12800 & 1.85 & 82 \\
\hline
\end{tabular}

a 2,7-Dibromo-9,9-di- $n$-octylfluorene (1.0 mmol), $\mathrm{NiCl}_{2}(0.07 \mathrm{mmol})$, zinc (3.1 mmol), $\mathrm{PPh}_{3}(0.28 \mathrm{mmol}), 2,2^{\prime}$-bpy $(0.042 \mathrm{mmol}), \mathrm{DMF} /$ toluene $(2 \mathrm{~mL}$, $20 / 80$ ), temperature $\left(80^{\circ} \mathrm{C}\right) .{ }^{\mathrm{b}} \mathrm{MW}$ : microwave (power max $\left.200 \mathrm{~W}\right)$, OB: oil bath. ' Determined by GPC analysis. ${ }^{d}$ Recovery $44 \%$.

On the other hand, in a nonpolar solvent, such as toluene, in which electron transfer is difficult to generate, before species I is reduced by zinc, it becomes inactive (species IV) by thermal decomposition, ${ }^{19}$ and therefore, the polymerization reaction is considered to cease.

Similar to above, the molecular weight and yield increased with an improved solubility by adjusting the solvent volume ratio. Again, the effect of the microwave irradiation time was examined (Table III). Decomposition of nickel-monomer complexes occurred due to the reaction in the toluene, and the formation rate of the polymer in the initial stage was slower than the DMF case (Entries 1 and 2). However, reactions longer than $80 \mathrm{~min}$ surpassed the DMF case (Entries 3-5). These results clearly show a large difference compared to the oil bath heating method. Thus, it seems that the microwave irradiation method accelerates this catalytic reaction. However, extending reaction time did not show a large change (Entries 6 and 7), possibly because the stirring efficiency is decreased and the viscosity is increased, which lower the reactivity.
Table IV. Effect of Monomer Concentration ${ }^{a}$

\begin{tabular}{cccccc}
\hline Entry & $\begin{array}{c}\text { Concentration } \\
(\mathrm{M})\end{array}$ & $\begin{array}{c}\text { Reaction time } \\
(\mathrm{min})\end{array}$ & $M_{\mathrm{w}} \mathrm{b}^{\mathrm{b}}$ & $M_{\mathrm{w}} / M_{\mathrm{n}}{ }^{\mathrm{b}}$ & $\begin{array}{c}\text { Yield } \\
(\%)\end{array}$ \\
\hline 1 & 0.25 & 180 & 20400 & 2.02 & 82 \\
2 & 0.35 & 180 & 23500 & 2.22 & 85 \\
3 & 0.40 & 180 & 24200 & 2.19 & 88 \\
4 & 0.50 & 180 & 22500 & 2.25 & 89 \\
5 & 0.25 & 300 & 21700 & 2.07 & 89 \\
\hline
\end{tabular}

a2,7-Dibromo-9,9-di- $n$-octylfluorene, $\mathrm{NiCl}_{2}$ (7 mol\%), zinc (3.1 eq.), $\mathrm{PPh}_{3}$ (28 mol\%), 2,2'-bpy (4.2 mol\%), DMF/toluene (2 mL, 20/80), temperature $\left(80^{\circ} \mathrm{C}\right.$, microwave power: $\left.\max 200 \mathrm{~W}\right)$. ' GPC analysis.

Table V. Scope of Functional Groups at the 9-Position ${ }^{\mathrm{a}}$

\begin{tabular}{|c|c|c|c|c|c|}
\hline Entry & $\mathrm{R}$ & $M_{\mathrm{w}}^{\mathrm{b}}$ & $M_{\mathrm{w}} / M_{\mathrm{n}}^{\mathrm{b}}$ & $\begin{array}{c}\text { Degree of } \\
\text { polymerization }\end{array}$ & $\begin{array}{l}\text { Yield } \\
(\%)\end{array}$ \\
\hline 1 & $\mathrm{H}$ & & & & $100^{\mathrm{d}, \mathrm{e}}$ \\
\hline 2 & $n$-Hexyl & 33300 & 2.40 & 100 & 90 \\
\hline 3 & n-Octyl & 24200 & 2.19 & 62 & 88 \\
\hline 4 & n-Dodecyl & 19200 & 1.84 & 38 & 83 \\
\hline 5 & 2'-Ethylhexyl & 16400 & 2.03 & 79 & 79 \\
\hline
\end{tabular}

a Monomer (0.8 mmol), $\mathrm{NiCl}_{2}(7 \mathrm{~mol} \%)$, zinc (3.1 eq.), $\mathrm{PPh}_{3}(28 \mathrm{~mol} \%)$, $2,2^{\prime}$-bpy $(4.2 \mathrm{~mol} \%)$, DMF/toluene $(2 \mathrm{~mL}, 20 / 80)$, temperature $\left(80^{\circ} \mathrm{C}\right.$, microwave power: $\max 200 \mathrm{~W})$, reaction time $(180 \mathrm{~min}) .{ }^{\mathrm{b}}$ Determined by GPC analysis. ${ }^{c}$ (Degree of polymerization) $=\left(M_{w}\right) /($ weight of monomer unit). ${ }^{d}$ Insoluble in any solvents. ${ }^{e}$ Conversion yield.

Hence, improving the stirring efficiency by decreasing the monomer concentration was examined (Table IV). With the identical reaction times, decreasing the monomer concentration decreased the yield because the concentration is related to the molecular collision frequency (Entries 1-4). This problem can be resolved by extending the reaction time (Entry 5).

Next, the scope of the 2,7-dibromofluorenes were examined (Table V). The degree of polymerization and yield were high when the alkyl group was short $(\mathrm{H}>n$-hexyl $>n$-octyl $>n$ dodecyl). Moreover, branched alkyl groups produced lower 
yields compared to primary alkyl chains (Entry 5). Hence, various factors, such as reactivity as well as the electrical and structural properties, seem to influence the polymerization reaction.

In summary, this study demonstrates that microwaveassisted and $\mathrm{Ni}$-catalyzed coupling polymerization can produce high yields of poly(2,7-fluorene)s in a short reaction time. It is sometimes explained that microwave acceleration for chemical reaction is so called the non-thermal effect but it is difficult to clarify that the energy of the microwave acts on what. In this coupling polymerization, however, microwave irradiation is very useful because the reaction is economical as well as much faster than the conventional method. Hence, it is concluded that this microwave-assisted method will improve practical applications of these types of materials.

We have undertaken it in clarifying what the microwave energy effectively works, and will come to report the result in the different paper, in the future.

Acknowledgment. This research was financially supported by "Carbon Nanotube Capacitor Development Project" of New Energy and Industrial Technology Development Organization (NEDO), Japan.

Received: December 24, 2008

Accepted: January 8, 2009

Published: February 18, 2009

\section{REFERENCES}

1. P. L. Burn, A. B. Holmes, A. Kraft, D. D. C. Bradley, A. R. Brown,
R. H. Friends, and R. W. Gywer, Nature, 356, 47 (1992).

2. G. Gustafsson, Y. Cao, G. M. Treacy, F. Klavetter, C. Colaneri, and A. J. Heeger, Nature, 357, 477 (1992).

3. Q. Pei, G. Yu, C. Zhang, Y. Yang, and A. J. Heeger, Science, 269 , 1086 (1995).

4. C. Shi, Y. Wu, W. Zeng, Y. Xie, K. Yang, and Y. Cao, Macromol. Chem. Phys., 206, 1114 (2005).

5. A. Kraft, A. C. Grimsdale, and A. B. Holmes, Angew. Chem., Int. Ed., 37, 402 (1998).

6. L. A. Bumm, J. J. Arnold, M. T. Cygan, T. D. Dunbar, T. P. Burgin, L. Jones, D. L. Allara, J. M. Tour, and P. S. Weiss, Science, 271, 1705 (1996).

7. G. Yu, J. Gao, J. C. Hummelen, F. Wudl, and A. J. Heeger, Science, 270, 1789 (1995).

8. "Lare Transition Metal Polymerization Catalysis," B. Rieger, L. Baugh, S. Kacker, and S. Striegler, Ed., Wiley-VCH, Weinheim, 2003.

9. "Transition Metal Catalysis in Macromolecular Design," L. S. Boffa and B. M. Novak, Ed., American Chemical Society, Washington DC, 2000.

10. J. Hassan, M. Sévignon, C. Gozzi, E. Schulz, and M. Lemaire, Chem. Rev., 102, 1359 (2002)

11. T. Yamamoto, Y. Hayashi, and A. Yamamoto, Bull. Chem. Soc. Jpn., 51, 2091 (1978).

12. T. Yamamoto, K. Osakada, T. Wakabayashi, and A. Yamamoto, Macromol. Chem. Rapid Commun., 6, 671 (1985).

13. M. Ueda and F. Ichikawa, Macromolecules, 23, 926 (1990).

14. A. de la Hoz, Á. D.-Ortiz, and A. Moreno, Chem. Soc. Rev., 34, 164 (2005).

15. C. O. Kappe, Angew. Chem., Int. Ed., 43, 6250 (2004).

16. P. Lidstrom, J. Tierney, B. Wathey, and J. Westman, Tetrahedron, 57, 9225 (2001).

17. M. Nüchter, B. Ondruschka, W. Bonrath, and A. Gum, Green Chem., 6, 128 (2004).

18. I. Colon and D. R. Kelsey, J. Org. Chem., 51, 2627 (1986).

19. A. Morvillo and A. Turco, J. Organomet. Chem., 208, 103 (1981). 